\title{
Laparoscopic repair of large paraoesophageal hernia with totally intrathoracic stomach
}

\author{
Johnny Martin O'Mahony, ${ }^{1,2}$ Simon Rajendran, ${ }^{1}$ Micheal Murphy, ${ }^{3}$ Deirdre O'Hanlon ${ }^{1}$
}

${ }^{1}$ Department of General Surgery, South Infirmary Victoria University Hospital, Cork, Ireland

${ }^{2}$ Department of Plastic Surgery, St James's Hospital, Dublin, Ireland

${ }^{3}$ Department of Radiology, South Infirmary Victoria University Hospital, Cork, Ireland

Correspondence to Dr Deirdre O'Hanlon, deirdreohanlon@hotmail.com

Accepted 18 August 2014

\section{DESCRIPTION}

A 55-year-old man presented with haematemesis on a background of 6 months of nausea, vomiting and $15 \mathrm{~kg}$ weight loss. He was clinically emaciated and dehydrated.

Chest X-ray demonstrated intrathoracic stomach with air-fluid levels within (figure 1A). Oesophagogastroscopy was performed, which demonstrated a large hiatus hernia with no evidence of bleeding. Follow-up CT and barium meal confirmed herniation of the entire stomach into the posterior mediastinum with associated mesenteroaxial volvulus (figure $1 \mathrm{~B}, \mathrm{C}$ ).

The patient underwent successful laparoscopic reduction of volvulus and repair of diaphragmatic hernia.

Gastric volvulus is defined as an acquired $180^{\circ}$ rotation of the stomach creating a closed loop obstruction. It can present with gastric outlet obstruction, ischaemia and/or perforation. ${ }^{1}{ }^{2}$ Borchardt's triad of epigastralgia, retching and inability to pass a nasogastric tube are classical symptoms. Gastric volvulus can be classified into three types based on the axis of rotation (figure $2 \mathrm{~A}, \mathrm{~B}, \mathrm{C})$. Organoaxial is the most common type and occurs when the stomach rotates along its long

\section{Learning points}

- Gastric volvulus is defined as an acquired $180^{\circ}$ rotation of the stomach creating a closed loop obstruction.

- Gastric volvulus can be classified based on the axis of rotation into organoaxial, mesenteroaxial and mixed types.

- Stable patients with no evidence of perforation can be successfully managed laparoscopically.
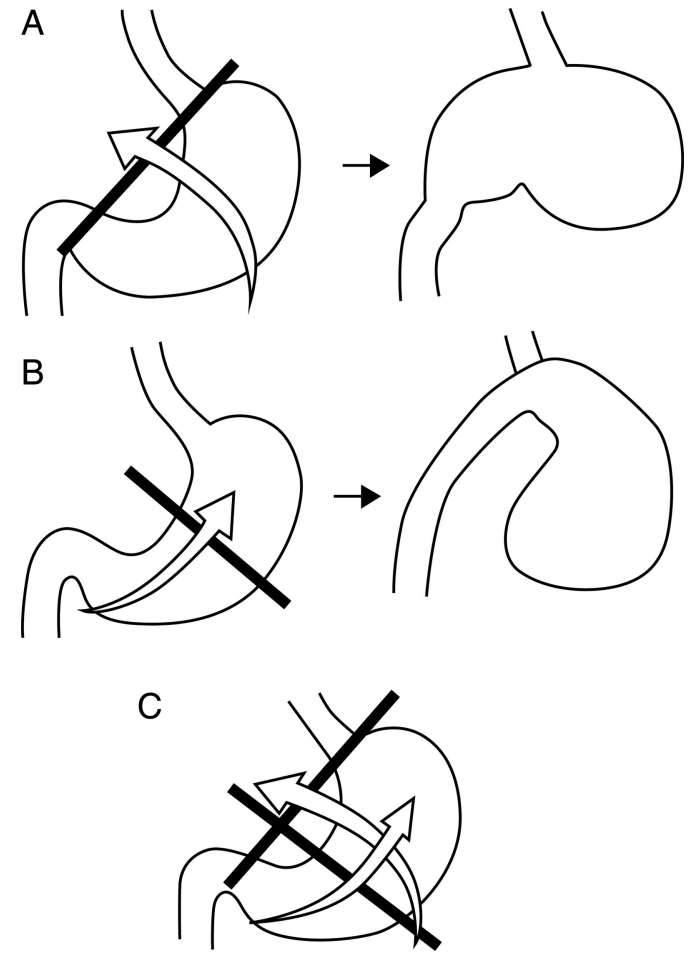

Figure 2 (A) Organoaxial volvulus (stomach rotates along its long axis). (B) Mesenteroaxial volvulus (the stomach rotates around the transgastric/short axis (a line connecting the middle of the lesser curvature with the middle of the greater curvature). (C) Mixed volvulus.

axis. Predisposing factors are a diaphragmatic defect or paraoesophageal hernia. Mesenteroaxial occurs when the stomach rotates around the transverse axis. Risk factors include abnormalities to gastric anchoring structures, for example, a long gastrohepatic ligament. The third type combines features of both. Ischaemia is more likely in mesenteroaxial and mixed types. Upper gastrointestinal

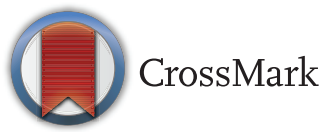

To cite: O'Mahony JM, Rajendran S, Murphy M, et al. BMJ Case Rep Published online: [please include Day Month Year] doi:10.1136/bcr-2014206472
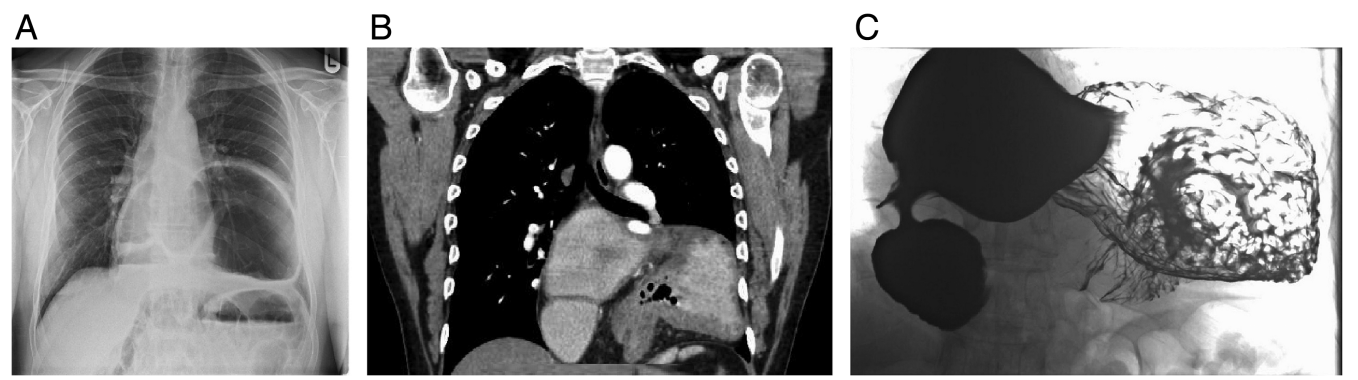

Figure 1 (A) Erect chest X-ray demonstrating intrathoracic stomach with air-fluid levels. (B and C) Coronal CT image and barium meal demonstrating complete gastric herniation into posterior mediastinum with associated volvulus and outlet obstruction. Gastro-oesophageal junction and fundus of stomach (arrow) seen at the same level as the duodenal bulb (arrowhead). 
tract contrast studies and CT are the imaging modalities of choice. Stable patients with no evidence of perforation can be managed laparoscopically with repair of hernial defect, ${ }^{3}$ while unstable patients require urgent open intervention.

Contributors JMO prepared, researched and wrote the article, and DO supervised it. MM was involved in radiology opinion and editing courtesy and further editorial insight was provided by SR.

Competing interests None.

Patient consent Obtained.
Provenance and peer review Not commissioned; externally peer reviewed.

\section{REFERENCES}

1 Toydemir T, Cipe G, Karatepe O, et al. Laparoscopic management of totally intra-thoracic stomach with chronic volvulus. World I Gastroenterol 2013;19:5848-54.

2 Targarona EM, Grisales S, Uyanik 0 , et al. Long-term outcome and quality of life after laparoscopic treatment of large paraesophageal hernia. World I Surg 2013;37:1878-82.

3 Lew PS, Wong AS. Laparoscopic mesh repair of parahiatal hernia: a case report. Asian J Endosc Surg 2013;6:231-3.

Copyright 2014 BMJ Publishing Group. All rights reserved. For permission to reuse any of this content visit http://group.bmj.com/group/rights-licensing/permissions.

BMJ Case Report Fellows may re-use this article for personal use and teaching without any further permission.

Become a Fellow of BMJ Case Reports today and you can:

- Submit as many cases as you like

- Enjoy fast sympathetic peer review and rapid publication of accepted articles

- Access all the published articles

- Re-use any of the published material for personal use and teaching without further permission

For information on Institutional Fellowships contact consortiasales@bmjgroup.com

Visit casereports.bmj.com for more articles like this and to become a Fellow 